Donald Campbell Award for being an outstanding methodological innovator in public policy studies; Senator Daniel Patrick Moynihan (D-NY), the Hubert Humphrey Award for being an outstanding public policy practitioner; Charles E. Lindblom, Yale University, the Harold D. Lasswell Award for outstanding scholarship in contributing to the understanding of the substance or process of public policy; Kathryn Moss, SUNY, Stonybrook, the Theodore Lowi Award for the best article in the Policy Studies Journol in 1987; L. A. Wilson II, Arizona State University, the Jeffrey Pressman Award for the best article in the Policy Studies Review in 1987; Christopher J. Bosso, Northeastern University and Abigail M. Thernstrom, Harvard University, the PSO Book Award for the best policy books in 1987; and Milton Heumann, Rutgers University, and Thomas Church, SUNY, Albany, the PSO Conference Paper Award for the best policy studies paper presented at a political science annual meeting in 1987.

\section{The Political Science Major}

The Association begins a study of the undergraduate major in political science in 1989. The study is to be a two-year effort under the direction of the Association of American Colleges. At least II other scholarly disciplines are participating in this project-entitled "Liberal Education, Study in Depth and the Arts and Science Major." Funding is being provided by the Fund for the Improvement of Post Secondary Education and The Ford Foundation.
A Task Force, appointed by Association President Lucian W. Pye, will examine the political science major. Task Force members are: John C. Wahlke, University of Arizona, chair; Twiley W. Barker, Jr., University of Illinois, Chicago; Lawrence $W$. Beer, Lafayette College; Mary Ellen Fischer, Skidmore College; Ronald Kahn, Oberlin College; Kathleen McGinnis, Trinity College; Marian L. Palley, University of Delaware; and Randall B. Ripley, Ohio State University. Serving on the Task Force, as ex-officio members in order to assure coordination with the Association's continuing programs, are: Richard Brody, Stanford University, chair, Education Committee; and Lois B. Moreland, Spelman College, chair, Departmental Services Committee.

The Task Force will examine existing practices for designing a major in political science in terms of credit hours, required courses, course sequences, proscribed areas of concentration, and the distribution across subfields. In doing so, the Task Force will address the objectives sought by a "study in depth" of political science and how these are pursued by departments of differing sizes and in different types of universities and colleges.

The Task Force will have some data from a survey of deans and department chairs organized by the AAC for the project. At the same time, the Task Force invites submissions from political science departments on the philosophy and structure of the major, and from individuals who have studied the major in political science. All of this information will be the basis of a report from the Task Force that will not only review current practices but recommend developments to strengthen the undergraduate major.

If anyone notices an omission in the newly published Directory of Black Americans in

Political Science, the Association would appreciate being informed. Please contact Maurice Woodard at APSA. 


\section{William Lewis Graf Awarded Joan Shorenstein Barone Congressional Fellowship}

William Lewis Graf, state capitol reporter, WISC-TV, Madison, Wisconsin, is the 1988-89 recipient of the Joan Shorenstein Barone Congressional Fellowship. He is the third individual to win the Fellowship, awarded each year to a broadcast journalist of outstanding merit.

Graf is currently working for Representative Al Swift (D-WA) on the House Subcommittee on Elections.

Funding is provided by the Walter and Phyllis Shorenstein Family in honor of their daughter, Joan Shorenstein Barone, a highly respected producer for CBS News who died in 1985 at a tragically early age.

\section{Kenton Bird Named Poynter Fellow}

Kenton Bird, editorial page editor Idahonian/Palouse Empire Daily News, Moscow, Idaho and Pullman, Washington, has been named the 1988-89 Poynter Fellow in the Congressional Fellowship Program.

For the past six years The Poynter Fund has generously provided direct support for APSA journalism Fellows, and this is the fourth year the Fund has supported a named Poynter Fellow. The first was Celia Cohen, senior statehouse reporter for the Wilmington News-journal newspapers. The 1986-87 Poynter Fellow was Andrew Pollack, reporter for The Democrat and Chronicle in Rochester, New York. William D. Zaferos, state and national political reporter for the Appleton, Wisconsin, Post-Crescent, was named in 1987-88.

The Poynter Fund is the charitable foundation of the Times Publishing Company whose publications include Congressional Quarterly Weekly Report and the family of

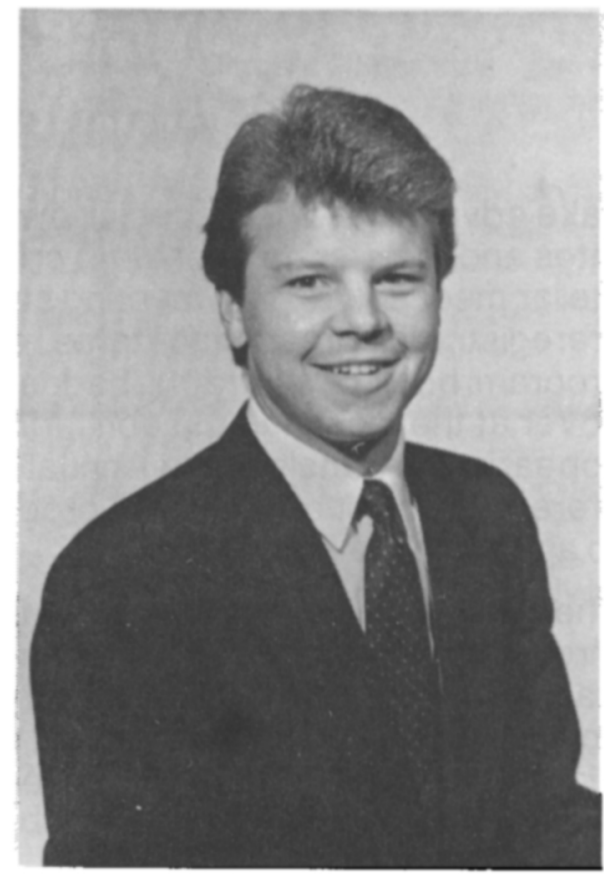

WILLIAM LEWIS GRAF

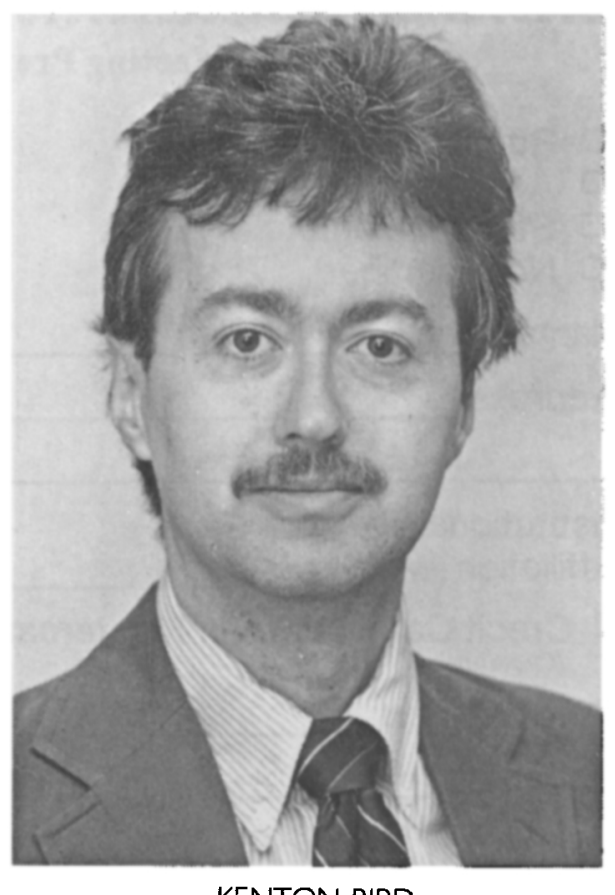

KENTON BIRD 


\section{Register now for the \\ 1989 Annual Meeting}

Take advantage of our special low preregistration rates and register now for what promises to be a stellar meeting. As past meeting attendees know, preregistration greatly facilitates receipt of your program, book of abstracts, badge and badge cover at the meeting. And don't forget that those appearing on panels at the Annual Meeting must preregister by June 1,1989 in order for their name to appear in the Final Program.

The 1989 APSA Meeting, which will be held from August 31 through September 3, 1989 in Atlanta, Georgia, will feature the traditional sections representing the major subfields of political science as well as six new topical sections including the Bill of Rights, the Civil Rights Act, the French Revolution, political science in Washington, D.C.. Thomas Hobbes and party realignment.

To register, fill out the form below and mail with your fee to: Annual Meeting Preregistration, The American Political Science Assn., 1527 New Hampshire Avenue, N.W., Washington, D.C. 20036.

\section{Annual Meeting Preregistration Form}

$\square$ Regular Member

Associate Member

Student Member of APSA

Non-member
$\$ 35$

$\$ 35$ Remittance MUST

$\$ 15$ accompany this form.

$\$ 60$ Return by August 1.

Name

Address

Institutional

Affiliation (tor badge)

Credit Card: VISA or Mastercard $\square$ Check enclosed (Circleone)

(Please make check payable to APSA)

Card number: Exp. Date:

Signature:

Questions? Please call us at (202) 483-2512. 
publications of Congressional Quarterly, Inc., as well as the St. Petersburg Times and Evening Independent. Andrew Barnes serves as President of the Poynter Fund and Chairman of the Board and Chief Executive Officer of Times Publishing Company.

\section{Corrections Noted for Biographical Directory}

The following corrections should be made for the 1988 APSA Biographical Directory.

Dexter, Lewis A. Birthdate: $1 / / \$ 3 / 15$. Current office address: Department of Political Science, University of North Carolina at Charlotte, Charlotte, NC
28223.

Garfinkel, Herbert. Springdale Drive should read as Springvale Drive in his home address.

Hanson, Elizabeth C. Incorrectly alphabetized under Elizabeth Crump. Please see Elizabeth Crump for biographical listing.

Schlesinger, Thomas 0 . Birthdate of $6 / 11 / 28$ should read as 6/1//25.

Sontag, Frederick H. Zip code of 07073 should read as 07079 .

Woodard, Maurice $C$. His business address should read as: Staff Associate, American Political Science Association, 1527 New Hampshire Avenue NW, Washington, DC 20036. 